\title{
Transient Heat input Model for Friction Stir welding using non-circular Tool Pin
}

Stephen Leon. J.

Research Scholar, Department of Mechanical Engineering, Saveetha school of Engineering Saveetha institute of Medical and -Technical Science, Chennai, India.

Jayakumar V. Amirtha School of Engineering, Amirtha vishwa Vidyapeetham,

Chennai, India.
Frictional heat source in the contact surface of a rotating tool and a stationary workpiece is used to join metal pieces along the weldline in the friction stir welding process. Temperature profile developed during welding decides the post weld properties on the joined workpieces not only along the weld line but also in the nearby layers of heat affected zone. As the heat input depends on the contact surface geometry in the tool/matrix interface, tool shape has a higher influence on peak temperature developed during the process and on the other hand it influences the post weld properties also. In this paper, a simplified analytical heat input model has been derived and validated for noncircular pin profile by introducing a new multiplication factor in the circular pin profile heat input model. Transient thermal numerical models are developed for, triangular, square and pentagonal pin profiles using analytical heat input results to analyse the change in temperature profiles with respect to the change in tool pin geometry. Furthermore, a detailed analysis is made to understand the percentage contribution of tool pin on the total heat supply.

Keywords: Friction sir welding, non-circular tool pin, heat input, thermal analysis.

\section{INTRODUCTION}

Friction stir welding is a plasticised solid-state metal joining process, which initially adopted to join easy oxidising materials like aluminium and further expanded now to weld other materials as it results enhanced properties on the weld joint comparing with other metal joining processes [1]. In this metal joining process, pin in the rotating tool is plunged into the firmly clamped workpiece until the shoulder contacts the top surface of the joint line and allowed to rotate for a while before translating it through the abutting edges to get weld joint. Heat required to join the edges is obtained by the friction on the tool/matrix interface, which is assisted by the heat generated through plastic deformation of the material during the process [2]. Temperature distribution during this process at various points along the workpiece decides the post weld properties and necessitates thermal modelling to optimise various physical parameters during FSW process. In thermal modelling based on relative motion between toll and workpiece the addition of heat source increases which is devided as three stages namely, plunge, dwell and welding. During plunge stage, friction between tool pin and workpiece produces heat and it does not produces major plastic deformation on the parental metal as it affects only the nearby layers [3]. In addition to this, enormous amount of heat is developed at the tool shoulder/matrix interface in dwell stage, soften workpiece material. In the welding stage, softened material undergoes huge strain due to the rotation and forward motion of tool, which

Received: October 2018, Accepted: April 2019

Correspondence to: J. Stephen Leon

Department of Mechanical Engineering, Saveetha

Institute of medical and technical science, India.

E-mail: stephenleonj@gmail.com

doi: $\mathbf{1 0 . 5 9 3 7 / f m e t 2 0 0 1 1 3 7 L ~}$

(C) Faculty of Mechanical Engineering, Belgrade. All rights reserved results additional heat source, as plastic deformation of material produces heat [4].

Measurement of temperature during welding using contact type measuring devices is difficult in the weldment due to the severe plastic deformation, which damages measuring probes. Several analytical models have been developed to investigate temperature distribution at different points, especially, in the weldment during the process. As the major heat source in FSW process is frictional heat in the interface of tool shoulder and workpiece, several models are developed under various contact conditions in the interface. Neglecting heat generated by the pin, analytical models are developed assuming workpiece material completely sticking with tool and tool completely sliding on the material [5] and partial sticking/sliding conditions [6]. Models are developed to calculate total heat generation through the input torque based on the experimental readings, by varying process parameters like tool rotation speed and contact pressure $[7,8]$. Peak temperature developed during welding is predicted [9] based on the torque input and corresponding temperature distribution at various points are predicted using numerical analysis [10] and optimised to enhance material properties of the workpiece. Heat generation due to the plastic deformation is obtained by analysing deformation rate and flow stress developed by the rotating tool. Thermomechanical coupled CFD model $[11,12]$ reveals the flow pattern and strain rate at various points in the weldment through which heat generation from viscous dissipation is calculated [13].

Apart from heat sources, temperature profile during welding is highly depends on fraction of rate of dissipation of heat through tool, backing plate, clamping device and other boundary conditions which are exposed to the atmosphere. Thermal conductivity between the workpiece and backing plate is remodified by considering thermal contact conductance [14]. A three dimensional 
FEM analysis is carried out to identify the amount of heat channelled through tool and other clamping systems [15]. Most of the heat transfer models were developed considering steady state conditions. However, plunge and dwell stage heat transfer steadies cannot be limited on steady state alone and several transient thermal models were developed coupled with material flow analysis on these stages [16-18]. Transient heat transfer in the weldment during dwell period plasticise the material under the tool shoulder and inturn assists free movement of tool pin along the weld line which improves the tool life by reducing tool wear rate [19].

Shape and dimension of tool pin have higher influence over post weld properties of the weld joint. Although its percentage contribution is limited in the total heat generation comparing with shoulder, for thick plate welding, considerable heat is produced by the tool pin [20]. In this paper, an equation is developed to identify a multiplication factor based on the number of sides in the pin profile, which is applied on the analytical heat generation model of the vertical pin surface. Further, the percentage contribution of tool pin over total heat generation and transient temperature distribution in the material during welding are analysed for different pin profiles by varying its dimensions.

\section{ANALYTICAL MODELLING}

To obtain simplified analytical equation following assumptions are made,

Heat transfer through backing plate and clamp is not considered and the entire surfaces of the workpiece except tool shoulder/workpiece interface are considered to be exposed to atmosphere.

As in dwell period major heat generation [20] is through friction, internal heat generation through plastic deformation is not taken into account.

As heat generation during plunging is comparatively lesser, it is neglected.

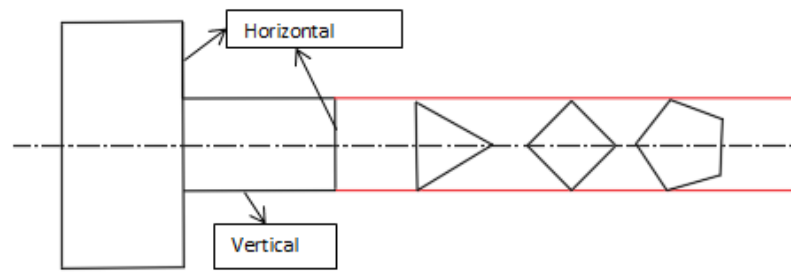

Figure 1. Tool pin shapes

For all tool pin geometry, there are three contacting surfaces. Two in horizontal direction (tool shoulder and tool pin tip) and one in vertical direction (vertical surface of tool pin) (ref fig. 1)

Total heat obtained by the horizontal surface is the addition of heat generated from shoulder and pin tip_and it is given by [21],

$$
\mathrm{Q}_{\text {Horizontal }}=\mathrm{Q}_{1}+\mathrm{Q}_{2}=\frac{2}{3} \pi \tau_{\text {contact }} \omega R_{\text {shoulder }}^{3}
$$

$\mathrm{Q}_{2}$ can be calculated by replacing $\mathrm{R}_{\text {shoulder }}$ by radius of the tool pin $\mathrm{R}_{\text {pin }}$ in the above equation

$$
\mathrm{Q}_{2}=\frac{2}{3} \pi \tau_{\text {contact }} \omega R_{\text {pin }}^{3}
$$

Heat generated for one pulse form the vertical contact surface is,

$$
\mathrm{Q}_{3}=\mathrm{Q}_{\text {vertical }}=\frac{2}{3} \pi \tau_{\text {contact }} \omega R_{\text {pin }}^{2} H_{\text {pin }}
$$

Here, $\mathrm{R}_{\mathrm{pin}}=\frac{a}{\sqrt{3}}$ for Triangular pin profile

$\mathrm{R}_{\text {pin }}=\frac{a}{2}$ for Square pin profile

$R_{\text {pin }}=0.8506$ a for Pentagonal pin profile

$\mathrm{R}_{\text {pin }}=\mathrm{a}$ for Hexagonal pin profile.

For the present analysis, in order to compare the effects of different pin profiles, pin side length (a) is selected in such a way to obtain uniform $R_{\text {pin }}$ value for all the pin shapes.

\section{TRANSIENT THERMAL MODELLING}

Transient thermal model is developed in ANSYS workbench based on the heat input value obtained from the analytical solutions for the different pin profile whose number of sides are increased from three to five. In order to compare temperature change during dwell period cut-off time is given as 12.5 seconds for all the pin profiles as the temperature cannot be raised more than $90 \%$ of the melting point of the parental metal [20]. Time taken to reach maximum temperature was also analysed for triangular, square and pentagonel pin profiles. Circular shape of the tool shoulder delivers an uniform heat supply in $\mathrm{X}$ and $\mathrm{Z}$ directions which results similar temperature change on those two directions. Change in temperature observed only in Y direction. So the model is limited with two dimensional cross section. Aluminium alloy 2024 plate is taken as workpiece. Properties workpiece and tool material and other parameters are given in Table 1\&2.

Table.1. Thermal properties of Aluminium 2024 with respect to temperature [22]

\begin{tabular}{|l|l|l|l|l|l|}
\hline $\begin{array}{l}\text { Temperature } \\
(\mathrm{K})\end{array}$ & 290 & 373 & 473 & 573 & 673 \\
\hline $\begin{array}{l}\text { Specific heat } \\
\text { capacity } \\
\left(\mathrm{J} \mathrm{Kg}^{-1} \mathrm{~K}^{-1}\right)\end{array}$ & 864 & 921 & 1047 & 1130 & 1172 \\
\hline $\begin{array}{l}\text { Thermal } \\
\text { conductivity } \\
\left(\mathrm{W} \mathrm{m}^{-1} \mathrm{~K}^{-1}\right)\end{array}$ & 120 & 134.4 & 151.2 & 172.2 & 176.4 \\
\hline
\end{tabular}

Table.2. Other data used in the modeling

\begin{tabular}{|l|l|}
\hline Property/parameter & Value \\
\hline Shoulder radius $(\mathrm{mm})$ & 7.5 \\
\hline Pin radius $(\mathrm{mm})$ & 2.5 \\
\hline Workpiece width $(\mathrm{mm})$ & 50 \\
\hline Workpiece thickness $(\mathrm{mm})$ & 6 \\
\hline Tool density $\left(\mathrm{Kg} / \mathrm{m}^{3}\right)$ & 7930 \\
\hline Workpiece density $\left(\mathrm{Kg} / \mathrm{m}^{3}\right)$ & 2780 \\
\hline $\begin{array}{l}\text { Specific heat capacity of tool } \\
\left(\mathrm{J} \mathrm{Kg}^{-1} \mathrm{~K}^{-1}\right)\end{array}$ & 502 \\
\hline $\begin{array}{l}\text { Thermal conductivity of tool } \\
\left(\mathrm{W} \mathrm{m} \mathrm{K}^{-1}\right)\end{array}$ & 21.4 \\
\hline $\begin{array}{l}\text { Heat transfer coefficient on the } \\
\text { surfaces of the workpiece exposed } \\
\text { to atmosphere. } \\
\left.\text { (W m } \mathrm{K}^{-2}\right)\end{array}$ & 200 \\
\hline
\end{tabular}




\subsection{Initial and Boundary condition:}

Heat flux at the tool shoulder and workpiece interface is given by

$$
\mathrm{k}\left(\left.\frac{\partial T}{\partial n}\right|_{\text {sholder }}\right)=\mathrm{Q}_{\text {horizontal }}-\mathrm{Q}_{2}
$$

in the range $R_{\text {pin }} \leq X \leq R_{\text {shoulder }}$ when time $t>0$

Heat flux at the tool pin tip and workpiece interface is given by

$$
\mathrm{k}\left(\left.\frac{\partial T}{\partial n}\right|_{\text {Pin-tip }}\right)=\mathrm{Q}_{2}
$$

in the range $0 \leq X \leq R_{\text {pin }}$ when time $t>0$

Heat flux at the tool pin vertical surface and workpiece interface is given by

$$
\mathrm{k}\left(\left.\frac{\partial T}{\partial n}\right|_{\text {Piin-vertical }}\right)=\mathrm{Q}_{3}
$$

in the range $0 \leq \mathrm{Y} \leq \mathrm{H}_{\text {pin }}$ when time $\mathrm{t}>0$

Heat loss from the workpiece surface other than the tool/matrix contact surface which is exposed directly to atmosphere is given by

$$
\mathrm{k}\left(\left.\frac{\partial T}{\partial n}\right|_{\text {Top-bottom-side }}\right)=\mathrm{h}_{\mathrm{x}}\left(\mathrm{T}_{\mathrm{x}}-\mathrm{T}_{\mathrm{amb}}\right),
$$

here $h_{x}$ and $T_{x}$ values are selected uniform for all worlpiece surfaces exposed to surounding medium.

An uniform initial temperature is assumed at all the nodes of the workpiece and tool.

$\mathrm{T}(\mathrm{x}, \mathrm{y})=\mathrm{T}_{\text {initial }}=22^{\circ} \mathrm{C}$ at any point when time $\mathrm{t}>0$

\section{RESULT AND DISCUSSION}

In order to compare the temperature distribution in the dwell period among different pin profiles, constant pin radius is modelled through the selection of opt pin side length for all pin geometries. Increase in temperature with respect to time during tool rotation in dwell period on welding Al2024 is observed for different pin profiles. For the validation of proposed heat input, total heat generated is calculated and compared with the analytical relationship developed by Gadakh et al [23], in which total heat generated by the different pin profiles are calculated by,

$\mathrm{Q}_{\text {Total }}=\frac{2}{3} \pi \tau_{\text {contact }} \omega\left(R_{\text {shoulder }}^{3}+X \cdot R_{\text {pin }}^{2} H_{\text {pin }}\right)$

Detailed comparison of heat generated by the different pin profiles through its vertical and horizontal surfaces are given in the table. 3

Table 3. Calculated heat input values for different pin profiles

\begin{tabular}{|c|c|c|c|c|c|}
\hline $\begin{array}{c}\text { Tool-pin } \\
\text { shape }\end{array}$ & $\begin{array}{c}\mathrm{Q}_{1} \\
(\mathrm{~W})\end{array}$ & $\begin{array}{c}\mathrm{Q}_{2} \\
(\mathrm{~W})\end{array}$ & $\begin{array}{c}\mathrm{Q}_{3} \\
(\mathrm{~W})\end{array}$ & $\begin{array}{c}\mathrm{Q}_{\text {total }} \\
(\mathrm{W})\end{array}$ & $\begin{array}{c}\mathrm{Q}_{\text {total }} \\
(\mathrm{W}) \\
{[22]}\end{array}$ \\
\hline Triangular & 4272 & 164 & 268 & 4705 & 4699 \\
\hline Square & 4272 & 164 & 357 & 4794 & 4785 \\
\hline Pentagonal & 4272 & 164 & 447 & 4884 & 4874 \\
\hline Hexagonal & 4272 & 164 & 536 & 4973 & 4964 \\
\hline
\end{tabular}

From the obtained values (Table.3.), it is understood that heat generated by the horizontal surface of tip of the pin remains same for all pin profiles as it is influenced only by the pin radius and not by the shape of the pin and will be equal to the heat generated by the circular pin profile. But there are considerable differences between the heat generated by the vertical surface of different pin profiles.

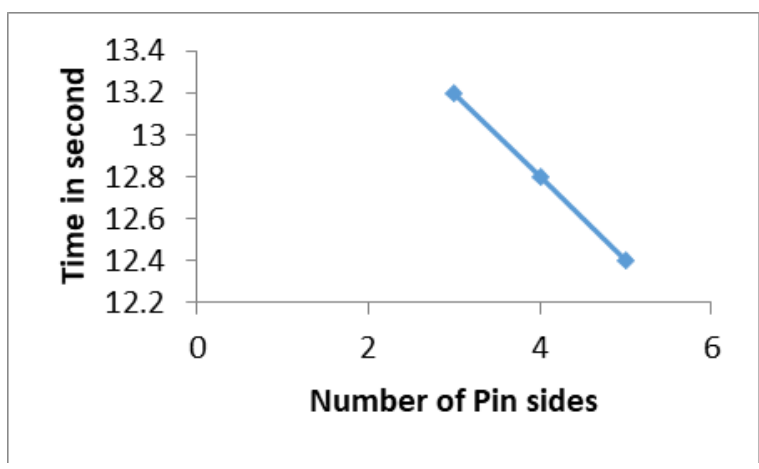

Figure 2. Time taken to attain Peak temperature (450 C)

Obtained results show that heat generated by the pin with hexagonal shape is equal to the heat generated by the circular pin as the increase in number of sides more than five results a shape much similar to the circular. From the fig.2, obtained from ANSYS transient analysis, it is understood time to attain peak temperature is inversely proportional to the number of sides in the pin.

When the number of sides in the ool pin inceased, although pin tip geomentries are diffeent, its contact area with workpiece is circular during rotation. So, Irrespective of heat supply surfaces, in the analytical calculation of total heat supplied by the horizontal surface of the tool depends only on shoulder diameter (ref eqn 1) and it remains same for circular and noncircular pin profiles. Variation in heat input is observed only in the vertical contact surface (Pin side). This reveals the importance of a generalised expression to calculate the heat generation by vertical surface of noncircular pin profiles and it can be written as,

$$
\mathrm{Q}_{\text {vertical }}=Y \tau_{\text {contact }} \omega a^{2} H_{\text {pin }}
$$

Here multiplication factor,

$$
\mathrm{Y}=0.1833 \mathrm{~N}^{2}-0.816 \mathrm{~N}+1.3 \text {, }
$$

where $\mathrm{N}$ denotes the number of sides and $\mathrm{Y}$ value should be restricted as maximum of 3 (fig.3).

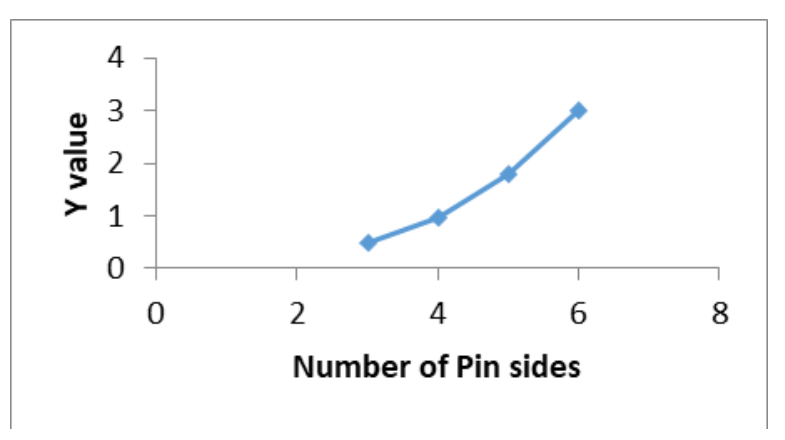

Figure 3. Multiplication value for different pin profiles

For hexagonal shape it attains maximum value of 3 and remains same for further increase in the number of 
sides as it leads to a shape closer to the shape of circle and the vertical frictional contact surface area is almost same. It reveals that heat input remains same for pin sides more than five and it will be equal to the circular shape.

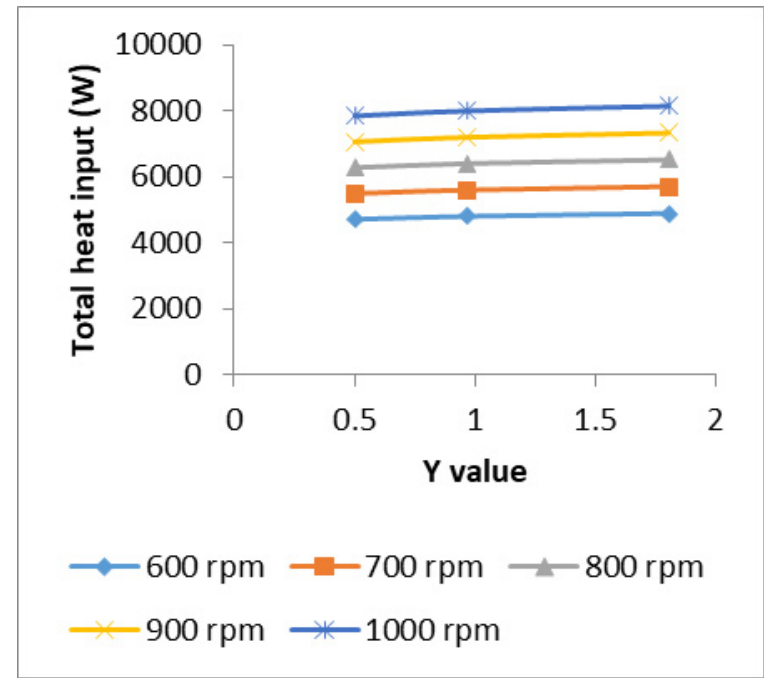

Fig.4. Increase in Total heat input with respect to the increase in $Y$ value.

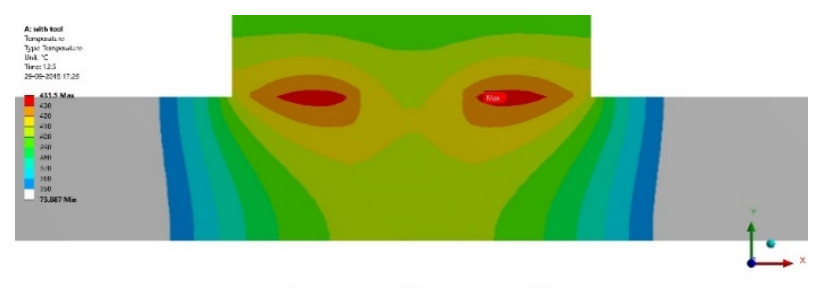

(a)

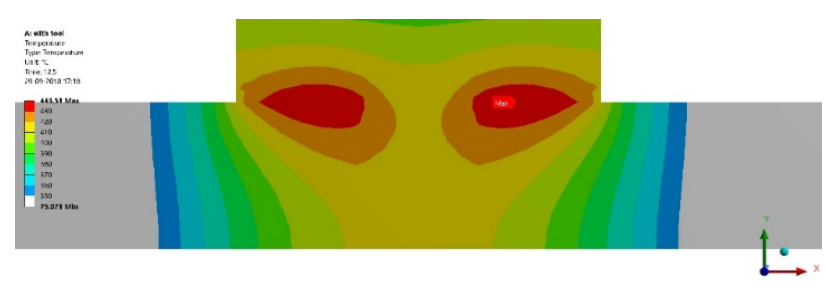

(b)

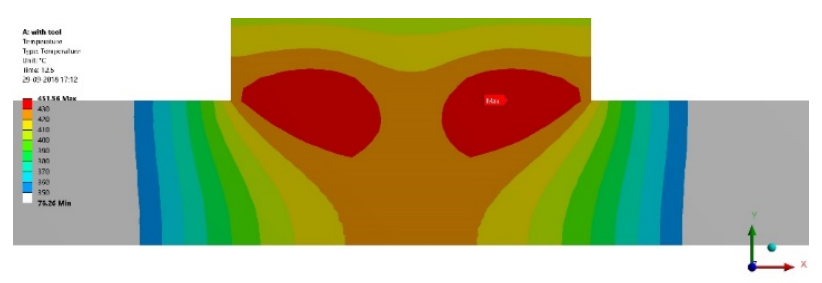

(c)

Figure 5. Temperature distribution during dwell period for

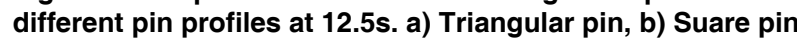
and c) Penagonal pin.

For the given input rotational speed, variation on heat input with respect to $\mathrm{Y}$ value is given in fig. 4. When Y value increases intensity of heat supply by the pin increases. It results quick plasticisation of the material beneath tool shoulder in the stir zone. It results less opposing force for the linear movement of the tool along the weld joint. So weld velocity can be increased [24]. It is understood that increase in $\mathrm{Y}$ value results increase in welding speed which reduces the size of the heat affected zone in which failure happens in FSW joints, because of less existence of needle shaped precipitate. High intensity heat supply not only reduces heat affected zone but also reduces the temperature gradient on the nearby zone around the vertical tool probe [25] (fig. 5). Reduction in temperature gradient reduces residual stress significantly.

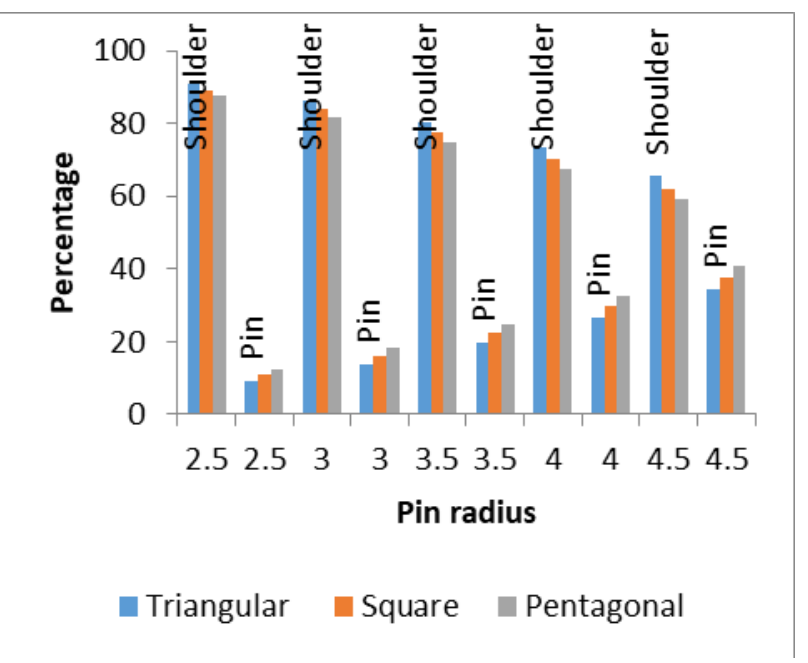

Figure 6.Comparison on Percentage contribution of tool shoulder and pin in total heat supply

Fig 6. shows the percentage contribution of tool pin in the total heat generation during the process. From the result, it can be concluded that major heat generation happens in the shoulder/matrix interface. Although the tool pin has a limited contribution on total heat supply, it increases with increase in pin diameter. It is observed that maximum contribution of tool pin on total heat input is achieved for pentagonal shape.

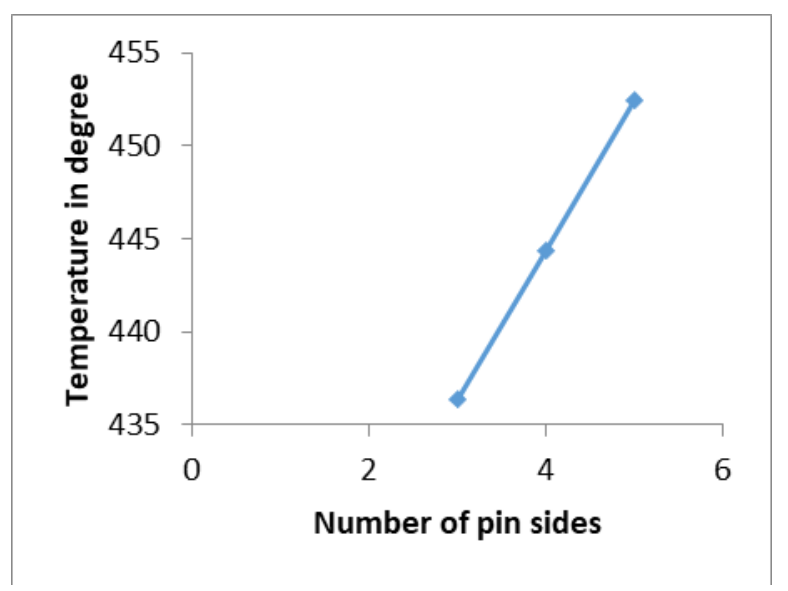

Figure 7. Peak temperature developed on different pin profiles at $12.5 \mathrm{~s}$.

From fig. 7, it is understood that the peak temperature produced during welding is directly proportional to the number of sides on the pin profile as the heat generation increases with the increase in number of sides. Previous comparative studies done on the post weld microstructure and other properties of weldment [26] justify the obtained value of heat generation through this analytical model. Higher heat generation rate during welding using pentagonal pin profile tool results better refined microstructure and higher tensile strength 
on the stir zone of the weldment. Increase in the heat generation on the pin/matrix interface reduces yield strength of the nearby layer of parental metal on the weld line. As a result, tool life increases as it experiences less opposing force during its transverse motion along the weld line. Reduction in yield strength not only reduces the stress on the tool pin but also it reduces flow stress among the metal layers under the shoulder in the stir zone which increases the strain rate and eases the stir joining process.

\section{CONCLUSIONS}

In this study, a transient thermal model was developed with the help of analytical heat input model for various non-circular pin profiles such as triangle, square and pentagon to estimate the time required to attain peak temperature during dwell. Developed numerical model based on analytical heat input reveals that time required to achieve peak temperature reduces with increase in the number of sides from triangle to pentagon and it was found that hexagonal pin profile gives almost similar result to the circular pin profile.

Furthermore, a new multiplication factor has been proposed to predict the dwell time, size of the heataffected zone and location of the peak temperature under the tool shoulder for various non-circular pin profiles. Percentage contribution of tool pin on the total heat supply is compared and it is observed that pentagonal shaped pin has higher value than other geometries. The reliability of the proposed model had been compared with the experimental results as the predicted values are closer to the measured values.

\section{REFERENCES}

[1] I.S.Stephan Thangaiah, P.Sevvel, C.Satheesh and V.Jaiganesh, Investigation on the Impingement of Parameters of FSW Process on the Microstructural Evolution \& Mechanical Properties of AZ80A Mg Alloy Joints, FME Transactions, 2018, 46, 23-32.

[2] Zhang Z. et al.: Coupled thermo-mechanical model based comparison of friction stir welding processes of AA2024-T3 in different thicknesses, Journal of material science 2011, 47(17) 5815-21.

[3] Zhang X.X, Xiao B.L, Mazy, A transient thermal model for friction stir weld part I: the model, metal mater, transfer A 2011: 42(10): 3218-28.

[4] Zhang X.X, Xiao B.L, Mazy, A transient thermal model for friction stir weld part II: effect of weld conditions, metal mater, transfer A 2011: 42(10): 3229-39.

[5] Colegrove P.A, Shercliff H.R, 3-Dimensional CFD modelling of flow round a threaded friction stir welding tool profile, Journal of material process technology, 2005: 169: 320-327.

[6] Schmidt H, Hattel J, Modelling thermosmechanical conditions at tool matrix interface in friction stir welding, fifth international symp. FSW, Metz, France. 2006.

[7] S.Cui, Z.W.Chen, J.D.Robson, A model relating tool torque and associated power and specific energy to rotation and forward speed durig friction stir welding/processing, Int. Journal of machine tools \& manufacture 50 (2010) 1023-1030.

[8] J.w.Pew, T.W. Nelson, C.D.Sorenson, Torque based weld power models for friction stir welding, Science and Technology of welding and joining 12 (2007) 341-347.

[9] S. Swaminathan, K. Oh-ishi, A.P. Zhilyaev, C.B. Fuller, B.London, M.W.Mohoney, Peak stir zone temperatures during friction stir processing, Metallurgical and materials transactions A 41 (2010) 631-640.

[10] Dongun Kim, Harsha Badarinarayan, Ji Hoon Kim, Chongmin Kim, Kazutaka Okamoto,R.H. Wagoner, Kwansoo Chung, Numerical simulation of friction stir butt welding process for AA5083-H18 sheets European Journal of Mechanics A/Solids 29 (2010) 204-215.

[11]J. Tang, Y. Shen, Numerical simulation and experimental investigation of friction stir lap welding between aluminum alloys AA2024 and AA7075, Journal of Alloys and Compounds (2016), 666, 493-500.

[12]A.N. Albakri, B. Mansoor, H. Nassar, M.K. Khraisheh, Thermo-mechanical and metallurgical aspects in friction stir processing of AZ31 Mg alloy - A numerical and experimental investigation, Journal of Materials Processing Technology 213 (2013) 279-290.

[13]R.Padmanaban, V.Ratnakishore and V.Balusamy, Numerical simulation of temperature distribution and material flow during friction stir welding of dissimilar aluminium alloys, Procedia Engineering 97 (2014) 854-863.

[14] A.Simer, J.Lecomte-Beckers, T.pardeon, B.de.Meester, Effect of boundary conditions and heat source on temperature in FSW, Science and Technology of welding and joining (2006) vol.11(2) 170-177.

[15] N.Contuzzi, S.L.Campahelli, G.Casalino and A.D.ludovico, On the role of the Thermal contact condition during friction stir welding of an AA5754-H11 butt joint, 2016, applied thermal engineering.

[16] R.Nandan, G.G.Roy, T.J.Lienert, T.Debroy, Threedimensional heat and material flow during friction stir welding of mild steel, Acta Materialia 55 (2007) 883-895.

[17] Cho H-H et al. Three-dimensional numerical and experimental investigation on friction stir welding processes of ferritic stainless steel. Acta Mater (2013), 61 (7):2649-2661

[18]H.Su, C.S.Wu, A.Pittner, M.Rethmeier, Thermal energy generation and distribution in friction stir welding of aluminum alloys, Energy (2014), vol.77, issue C, 720-731.

[19] R.Rai, A.De, H.K.D.H.Bhadeshia and T.DebRoy, Review: friction stir welding tools, Science and Technology of Welding and Joining 2011, Vol.16, No.4, 325-342. 
[20]C.Hamilton, S.Dymek, A.Sommers, A thermal model of friction stir welding in aluminum alloys, International Journal of Machine Tools \& Manufacture 48 (2008) 1120-1130.

[21] Schmidt H, Hattel J and J Wert, An analytical model for the heat generation in friction stir welding, Modelling simul.Mater.Sci.Engg. 12 (2004) 143-157.

[22] L.Shi, C.S.Wu., Transient model of heat transfer and material flow at different stages of friction stir process, Journal of manufacturing processes 2017; 25: 323-339.

[23] V.S.Gadakh, A.Kumar G.J.Vikhe patil, Analytical Modeling of the Friction Stir Welding Process Using Different Pin Profiles, Welding Journal, New York; (2015) 94, 4; 115s-124s.

[24] A.Arora, A.de and T.DebRoy, Toward optimum friction stir welding tool shoulder diameter, Scripta Materialia 64,(2011), 9-12.

[25] S.Sadeghi, N.Zarif Karimi, M.Fotouhi, M.Hasani, M.Ahmadi Najafabadi and A.Pavlovic, Residual Stress Evaluation in Friction Stir Welding of Aluminum Plates by Means of Acoustic Emission and Ultrasonic Waves, FME Transactions, 2018, 46, 230-237.

[26] R.Palanivel, P. Koshy Mathews, M. Balakrishnan, I. Dinakaran, N. Murugan: Effect of tool pin profile and axial force on tensile behavior in friction stir welding of dissimilar aluminum alloys Advanced Materials Research Vols. 415-417 (2012) pp 1140-1146.

\section{NOMENCLATURE}

$\mathrm{Q}_{1} \quad$ Heat generated in the shoulder/matrix interface.

$\mathrm{Q}_{2}$ Heat generated in the tool pin/matrix interface.

$\mathrm{Q}_{3} \quad$ Heat generated in the tool vertical surface/matrix interface.

$h_{x} \quad$ local heat transfer coefficient

$\mathrm{R}_{\text {Shoulder }} \quad$ Tool shoulder radius

$\begin{array}{ll}\mathrm{R}_{\text {Pin }} & \text { Tool pin radius } \\ \mathrm{H}_{\text {pin }} & \text { Tool pin height } \\ \mathrm{a} & \text { Length of the pin side } \\ \mathrm{T}_{\mathrm{x}} & \text { Work piece surface temperature } \\ \mathrm{T}_{\mathrm{amb}} & \text { Temperature of surrounding medium } \\ \mathrm{P} & \text { Contact pressure }\end{array}$

\section{Greek symbols}

$\begin{array}{ll}\tau_{\text {contact }} & \text { Contact stress } \\ \mu & \tau_{\text {contact }}=\mu \mathrm{P} \\ \mu & \text { Friction coefficient }\end{array}$

\section{МОДЕЛ УЛАЗА ПРОЛАЗНЕ ТОПЛОТЕ КОД \\ ЗАВАРИВАЊА ТРЕЊЕМ СА МЕШАЊЕМ КОРИШЪЕЊЕМ НЕКРУЖНЕ ИГЛЕ АЛАТА}

\section{С. Леон Ј., Јајакумар В.}

Извор топлоте настале трењем код додирних површина ротирајућег алата и стационарног обратка се користи за спајање металних делова по линији заваривања у процесу заваривања трењем. Профил температуре која се развија током заваривања одређује својства вара код спојених делова не само по линији заваривања већ и у околним слојевима зоне утицаја топлоте. Пошто улаз топлоте зависи од геометрије додирних површина код интерфејса алата и матрице, облик алата има већи утицај на максималну температуру током заваривања, а такође утиче и на својства шава после заваривања. У раду је развијен и евалуиран поједностављени аналитички модел улаза топлоте за профил некружне игле увођењем фактора множења у модел улаза топлоте за профил кружне игле. Нумерички модели пролазне топлоте су развијени за иглу профила троугла, четвороугла и петоугла применом резултата анализе промене температуре профила у односу на промену геометрије игле алата. Извршена је детаљна анализа процента доприноса игле алата укупном доводу топлоте. 